\title{
Differential valine metabolism in adipose tissue of low and high fat-oxidizing obese subjects.
}

Citation for published version (APA):

Claessens, M., Saris, W. H. M., Bouwman, F. G., Evelo, C. T. A., Hul, G. B. J., Blaak, E. E., \& Mariman, E. C. M. (2007). Differential valine metabolism in adipose tissue of low and high fat-oxidizing obese subjects. Proteomics Clinical Applications, 1(10), 1306-1315. https://doi.org/10.1002/prca.200700049

Document status and date:

Published: 01/01/2007

DOI:

10.1002/prca.200700049

Document Version:

Publisher's PDF, also known as Version of record

Document license:

Taverne

Please check the document version of this publication:

- A submitted manuscript is the version of the article upon submission and before peer-review. There can be important differences between the submitted version and the official published version of record.

People interested in the research are advised to contact the author for the final version of the publication, or visit the DOI to the publisher's website.

- The final author version and the galley proof are versions of the publication after peer review.

- The final published version features the final layout of the paper including the volume, issue and page numbers.

Link to publication

\footnotetext{
General rights rights.

- You may freely distribute the URL identifying the publication in the public portal. please follow below link for the End User Agreement:

www.umlib.nl/taverne-license

Take down policy

If you believe that this document breaches copyright please contact us at:

repository@maastrichtuniversity.nl

providing details and we will investigate your claim.
}

Copyright and moral rights for the publications made accessible in the public portal are retained by the authors and/or other copyright owners and it is a condition of accessing publications that users recognise and abide by the legal requirements associated with these

- Users may download and print one copy of any publication from the public portal for the purpose of private study or research.

- You may not further distribute the material or use it for any profit-making activity or commercial gain

If the publication is distributed under the terms of Article $25 \mathrm{fa}$ of the Dutch Copyright Act, indicated by the "Taverne" license above, 


\title{
Differential valine metabolism in adipose tissue of low and high fat-oxidizing obese subjects
}

\author{
Mandy Claessens ${ }^{1}$, Wim H. M. Saris ${ }^{1}$, Freek G. Bouwman ${ }^{1}$, Chris T. A. Evelo ${ }^{2}$, \\ Gabby B. J. Hul' ${ }^{1}$ Ellen E. Blaak ${ }^{1}$ and Edwin C. M. Mariman ${ }^{1}$ \\ ${ }^{1}$ Department of Human Biology, Nutrition and Toxicology, Research Institute Maastricht, \\ Maastricht University, Maastricht, The Netherlands \\ ${ }^{2}$ BiGCaT Bioinformatics, Nutrition and Toxicology, Research Institute Maastricht, \\ Maastricht University, Maastricht, The Netherlands
}

Differences in fat metabolism are of importance in relation to energy balance. Low fat-oxidizers (LFO) are thought to be more prone for developing obesity. We studied whether LFO have dif-

Received: January 18, 2007

Revised: March 20, 2007 ferent fasting adipose tissue (AT) protein profiles than high fat-oxidizers (HFO). Six LFO and six HFO subjects were selected from an obese group ( $n=99$, body mass index $\left.>30 \mathrm{~kg} / \mathrm{m}^{2}\right)$ taking part in a multi-center study (Nutrient-Gene interaction in human obesity) based on the postprandial fat oxidation capacity after a high fat load. AT protein profiles were studied by 2-DE. Differential proteins were clustered with MAPPfinder according to their function. Protein profiles of purified blood cells and adipocytes served to confine the comparison to adipocyte-specific proteins in AT profiles of LFO and HFO subjects. LFO had increased mitochondrial ROS scavengers possibly related to long-chain unsaturated fatty acid-induced increases in mitochondrial ROS-production. Carbohydrate oxidation seemed to be reduced since expression of several proteins from the glycolysis pathway was lower in LFO. Up-regulation of the valine catabolism at the level of methylmalonate-semialdehyde dehydrogenase appeared to be (part of) the compensatory mechanism. In conclusion, the fasting AT protein profile of LFO and HFO differ at the level of ROS scavenging, the glycolysis pathway and valine metabolism.

\section{Keywords:}

Adipose tissue / Obesity / Valine metabolism

\section{Introduction}

Obesity is a complex disorder to which genetic predisposition, environmental factors and metabolic factors contribute [1-3]. Long-term weight maintenance (energy balance)

Correspondence: Dr. Ellen E. Blaak, Department of Human Biology, NUTRIM, P.O. Box 616, 6200 MD Maastricht, The Netherlands E-mail: e.blaak@hb.unimaas.nl

Fax: +31-43-367-0976

Abbreviations: AT, adipose tissue; BMI, body mass index; EN\%, energy percentage; FFA, free fatty acids; FFM, fat free mass; HFO, high fat-oxidizer; LFO, low fat-oxidizer; MMSDH, methylmalonate-semialdehyde dehydrogenase; NUGENOB, Nutrient-Gene interaction in human obesity; $\mathbf{R} \mathbf{Q}$, respiratory quotient requires sustained macronutrient balance, that is when the fuel mix consumed is equal to the fuel mix oxidized (WHO. Obesty: Preventing and managing the global epidemic, Geneva, 2000). Consumption of dietary carbohydrate leads to increased carbohydrate oxidation mainly through the action of insulin [1], whereas a high-fat diet does not increase fat oxidation acutely [2, 3, 4]. Limited capacity to adjust fat oxidation to intake may translate into a positive fat balance and weight gain when individuals are exposed to a high-fat diet. In general, obese subjects have a decreased capacity to use fat as a fuel and adapt more slowly to a high fat intake than lean subjects [4-7]. Post-obese women [8] or women predisposed to develop obesity [5] have a lower postprandial and $24 \mathrm{~h}$ fat oxidation as compared to never-obese women. Furthermore, a longitudinal study in Pima Indians of Arizona showed that 
low fat-oxidizers have greater risk of gaining weight over time as compared to high fat-oxidizers [7]. Thus, there is accumulating evidence that a primary, possibly genetically determined component of fat metabolism might result in a low fat oxidation rate predisposing subjects to develop obesity. In the recent NUtrient-GENe interaction in human OBesity (NUGENOB) trial (European multi-center study) we had the unique opportunity to study the fat oxidation rate in a large cohort of obese subjects with a wide range of adiposity and in a lean reference group both before and after ingestion of a high-fat load $[9,10]$. Results of this study confirm that postprandial fat oxidation decreases with body mass index (BMI), an effect only present in those subjects with a relatively low fasting fat oxidation [10]. Although fat oxidation takes place mainly in oxidizing tissues like skeletal muscle and liver, we reasoned that a disturbance in fat oxidation in these tissues would influence the flow of fatty acids towards adipose tissue (AT) and would thereby lead to an adjustment in metabolic gene expression in AT.

In the present study we investigated, by means of proteomics, whether obese high fat-oxidizers (HFO) have different AT protein profiles when compared to low fat-oxidizers (LFO).

\section{Materials and methods}

\subsection{Materials}

Collagenase, CHAPS, DTT, iodoacetamide, CHCA, alcohol dehydrogenase and adrenocorticotropic hormone fragment 18-39 were from Sigma (St. Louis, MO, USA). Urea was from Bio-Rad (Veenendaal, The Netherlands). Immobiline Dry Strips pH 3-10 Linear $24 \mathrm{~cm}$ long were from Amersham Biosciences (Little Chalfont, England). Sequencing grade modified trypsin was obtained from Promega (Madison, WI, USA).

\subsection{Subjects}

This study is part of the NUGENOB multi-center study which is described in detail elsewhere [9]. The study was approved by the Ethical Committee at each of the participating centers. Volunteers were informed about the nature of the study and written consent was obtained at the start of the study. For this study only the obese Maastricht participants were included. Inclusion criteria were among others a BMI $>30 \mathrm{~kg} / \mathrm{m}^{2}$. From the 99 obese participants a selection of six subjects with a high fat oxidative capacity, HFO, and six subjects with a low fat oxidative capacity, LFO, was made. Approximately $75 \%$ of all subjects was female [9] and as a consequence both groups of six subjects consisted of five females and one male. To characterize subjects as HFO and LFO the response to a saturated fat load was measured (see below). LFO and HFO subjects were selected and matched for body weight, age and fat free mass. Since we were inter- ested in differences in AT proteome profile between HFO and LFO, we searched for differences in fat biopsies taken before the original intervention period.

\subsubsection{Experimental day}

Subjects were asked to refrain from drinking alcohol, smoking, and strenuous exercise $24 \mathrm{~h}$ before experimental days. Subjects came to the laboratory by car or bus in the morning after an overnight fast. The liquid test meal (energy content fixed at $50 \%$ of predicted basal metabolic rate) consisted of 3 energy percentage (EN\%) carbohydrate, 2 EN\% protein and 95 EN\% fat of which $60 \%$ was saturated [10]. Fasting (30 min) and postprandial (180 min) fat oxidation were measured by means of ventilated hood measurements [10]. Subjects with fasting and postprandial fat oxidation higher than the $50^{\text {th }}$ percentile (expressed relative to energy expenditure) were considered as $\mathrm{HFO}$ and subjects with fasting and postprandial fat oxidation lower than the $50^{\text {th }}$ percentile were considered as LFO.

\subsubsection{Fat biopsy}

Abdominal subcutaneous AT biopsies $(\sim 1.5 \mathrm{~g})$ were obtained from the para-umbilical region by needle liposuction under local anesthesia (2\% lidocaine with adrenalin 1:80 000, AstraZeneca BV, The Netherlands). The tissue was immediately washed in cold saline, frozen in liquid nitrogen and stored at $-80^{\circ} \mathrm{C}$ until protein isolation.

\subsubsection{Anthropometric measurements}

Subjects underwent measurements of body weight, body composition and body fat distribution as described elsewhere [9]. Briefly, body weight was measured with a calibrated scale with subjects in their underwear. Measurements were performed three times and the mean was recorded. Body composition was determined by a multi-frequency bio-impedance meter (Bodystat, Quadscan 4000, Isle of Man, British Isles) with subjects in supine position [10].

\subsection{Adipocyte isolation}

Isolation of adipocytes was based on the method of Rodbell [11], with minor modifications. Within minutes after obtaining a biopsy, AT was cut into small fragments and incubated with $2 \mathrm{mg} / \mathrm{mL}$ collagenase, followed by gently shaking in an incubator (humidified, $5 \% \mathrm{CO}_{2}$ and $95 \%$ air) at $37^{\circ} \mathrm{C}$ for $45 \mathrm{~min}$ in $\mathrm{KRBH}$ buffer (Krebs Ringer bicarbonate supplemented with HEPES containing $25 \mathrm{mM} \mathrm{NaHCO}, 1.2 \mathrm{mM}$ $\mathrm{KH}_{2} \mathrm{PO}_{4}, 4.8 \mathrm{mM} \mathrm{KCl}, 1.2 \mathrm{mM} \mathrm{MgSO}, 118 \mathrm{mM} \mathrm{NaCl}$, $1.25 \mathrm{mM} \mathrm{CaCl}_{2}$ and $10 \mathrm{mM}$ HEPES, pH 7.4) containing $4 \%$ BSA. The cell suspension was then filtered through $500 \mu \mathrm{m}$ nylon mesh and spun at $220 \times \mathrm{g}$ for $1 \mathrm{~min}$ to separate stromal vascular cells and mature adipocytes. Floating isolated adipocytes were washed three times with KRBH buffer supplemented with $0.3 \%$ BSA [12]. 


\subsection{Sample preparation}

\subsubsection{Biopsy}

About $350 \mathrm{mg}$ tissue from the biopsies was washed in PBS to get rid of the major part of blood and grind in a mortar with liquid nitrogen. The powder was dissolved in $200 \mu \mathrm{L} 8 \mathrm{M}$ urea, 2\% w/v CHAPS, $65 \mathrm{mM}$ DTT per $100 \mathrm{mg}$ biopsy. The homogenate was vortexed for $5 \mathrm{~min}$ and centrifuged at $20000 \times \mathrm{g}$ for $30 \mathrm{~min}$ at $10^{\circ} \mathrm{C}$. The supernatant was carefully collected and aliquots were stored at $-80^{\circ} \mathrm{C}$. Routinely, we do not use protease inhibitors since they may disturb the analysis. Indeed, protein proteolysis was found to be minimal because, from all 26 identified proteins, only one (very-longchain acyl CoA synthetase) was detected as a partial protein (Table 2).

\subsubsection{Adipocytes}

Isolated adipocytes were resuspended in $8 \mathrm{M}$ urea, $2 \% \mathrm{w} / \mathrm{v}$ CHAPS, 65 mM DTT. Adipocytes were lysed by subjecting them to three cycles of quick freezing in liquid nitrogen and subsequent thawing. The homogenate was vortexed for $1 \mathrm{~min}$ and centrifuged at $20000 \times \mathrm{g}$ for $30 \mathrm{~min}$ at $10^{\circ} \mathrm{C}$. The supernatant was carefully collected and aliquots were stored at $-80^{\circ} \mathrm{C}$.

Protein concentrations were determined by a Bradford based protein assay [13].

\subsubsection{Blood cells}

Leukocytes and erythrocytes were isolated from an EDTA containing blood sample. First the blood sample was centrifuged at $1000 \times \mathrm{g}$ at $4^{\circ} \mathrm{C}$ for $10 \mathrm{~min}$. Afterwards plasma was discarded and erythrocytes were mixed with the buffy coat. This mixture was washed three times with $0.9 \% \mathrm{NaCl}$ buffered with PBS. Leukocytes and erythrocytes were resuspended in $8 \mathrm{M}$ urea, 2\% w/v CHAPS and $65 \mathrm{mM}$ DTT and they were lysed by subjecting them to three cycles of quick freezing in liquid nitrogen and subsequent thawing. The homogenate was vortexed for $1 \mathrm{~min}$ and centrifuged at $20000 \times \mathrm{g}$ for $30 \mathrm{~min}$ at $10^{\circ} \mathrm{C}$. The supernatant was carefully collected and aliquots were stored at $-80^{\circ} \mathrm{C}$.

Protein concentrations were determined by a Bradford based protein assay [13]

\section{$2.52-\mathrm{DE}$}

From all 12 protein solutions $150 \mu \mathrm{g}$ of total protein was loaded for the first dimension. IEF was preformed on a IPG PHOR electrophoresis unit (Amersham Biosciences) at $20^{\circ} \mathrm{C}$. Immobiline Dry Strips ( $\mathrm{pH} 3-10$ Linear, $24 \mathrm{~cm}$ long) were rehydrated overnight in $500 \mu \mathrm{L}$ of $8 \mathrm{M}$ urea, $2 \% \mathrm{w} / \mathrm{v}$ CHAPS, $65 \mathrm{mM}$ DTT, 0.5\% v/v IPG buffer $\mathrm{pH}$ 3-10 Linear at $30 \mathrm{~V}$. IEF was performed using the following program: $500 \mathrm{~V}$ for $1 \mathrm{~h}, 1000 \mathrm{~V}$ for $1 \mathrm{~h}, 1000-8000 \mathrm{~V}$ for $2 \mathrm{~h}$ and a final step of $8000 \mathrm{~V}$ for $52000 \mathrm{~V} \cdot \mathrm{h}$. After focusing, IPG strips were equi- librated for $15 \mathrm{~min}$ in $50 \mathrm{mM}$ Tris-HCl, pH 6.8, $6 \mathrm{M}$ urea, $30 \% \mathrm{v} / \mathrm{v}$ glycerol, $2 \% \mathrm{w} / \mathrm{v}$ SDS, $1 \% \mathrm{w} / \mathrm{v}$ DTT and for $15 \mathrm{~min}$ in $50 \mathrm{mM}$ Tris- $\mathrm{HCl}, \mathrm{pH}$ 6.8, $6 \mathrm{M}$ urea, $30 \% \mathrm{v} / \mathrm{v}$ glycerol, $2 \%$ $\mathrm{w} / \mathrm{v}$ SDS, $2.5 \% \mathrm{w} / \mathrm{v}$ iodoacetamide, and were placed onto a slab gel and sealed with a $0.5 \% \mathrm{w} / \mathrm{v}$ agarose solution in Laemmli buffer with a trace of bromophenol blue. The second-dimension run was carried out on $12.5 \%$ SDS-PAGE gels. Electrophoresis was conducted at a constant voltage of $200 \mathrm{~V}$ for $5 \mathrm{~h}$ in a $24 \mathrm{~cm}$ Dodeca Cell (Bio-Rad) [14-16]. After electrophoresis, proteins were fixed in 50\% methanol, $5 \%$ acetic acid in water for $1 \mathrm{~h}$. Gels were then washed overnight with $50 \%$ methanol and additionally rinsed three times for $10 \mathrm{~min}$ with water. They were sensitized by $3 \mathrm{~min}$ incubation in $0.02 \%$ sodium thiosulfate and rinsed with three changes of distilled water for $10 \mathrm{~min}$ each. After rinsing, gels were submerged in a $0.1 \%$ silver nitrate solution and incubated for $1 \mathrm{~h}$. Silver nitrate was discarded, and gels were rinsed twice with water for $1 \mathrm{~min}$ and then developed in $0.04 \%$ formalin (35\% formaldehyde) in $2 \%$ sodium carbonate with intensive shaking. After the desired intensity of staining was achieved, the development was terminated by washing the gels with $5 \%$ acetic acid for $5 \mathrm{~min}$. Silver-stained gels were stored in water at $4^{\circ} \mathrm{C}$ until analysis $[16,17]$. Gel images were obtained with a GS-800 calibrated densitometer (Bio-Rad). Spot detection and matching was performed with the PD Quest v7.3 software package (Bio-Rad). Gel images were normalized on the adipocyte specific spots. Fold changes were obtained by dividing the average spot intensity $(n=6)$ of the LFO group by that of the HFO group. Molecular weight values were estimated using standard MW-markers.

\subsection{In-gel digestion}

Protein spots were excised from gels using an automated spot cutter (Bio-Rad) and processed on a MassPREP digestion robot (Waters, Manchester UK). A solution of 1.0\% v/v $\mathrm{H}_{2} \mathrm{O}_{2}$ was used for silver destaining [18]. Cysteines were reduced with $10 \mathrm{mM}$ DTT in $100 \mathrm{mM}$ ammonium bicarbonate for $30 \mathrm{~min}$ followed by alkylation with $55 \mathrm{mM}$ iodoacetamide in $100 \mathrm{mM}$ ammonium bicarbonate for $20 \mathrm{~min}$. Spots were washed with $100 \mathrm{mM}$ ammonium bicarbonate to remove excess reagents and were subsequently dehydrated with $100 \%$ ACN. Trypsin $(6 \mathrm{ng} / \mu \mathrm{L})$ in $50 \mathrm{mM}$ ammonium bicarbonate was added to the gel plug and incubation was performed at $37^{\circ} \mathrm{C}$ for $5 \mathrm{~h}$. Peptides were extracted in $30 \mu \mathrm{L}$ of $1 \% \mathrm{v} / \mathrm{v}$ formic acid $/ 2 \% \mathrm{v} / \mathrm{v}$ ACN in water for $30 \mathrm{~min}$ at room temperature. The peptide extract was removed and a second extraction was performed using $24 \mu \mathrm{L}$ of $50 \% \mathrm{v} / \mathrm{v}$ $\mathrm{ACN}$ in water for $20 \mathrm{~min}$ at room temperature. Both peptide extractions were kept separately for MS analysis [16-18].

\subsection{MS}

For MALDI-TOF MS $1.5 \mu \mathrm{L}$ of peptide mixture and $0.5 \mu \mathrm{L}$ matrix solution $(2.5 \mathrm{mg} / \mathrm{mL}$ CHCA in $50 \%$ ACN/0.1\% TFA) was spotted automatically onto a 96 well-format target plate. 
Spots were allowed to air dry for homogeneous crystallization. Spectra were obtained using an M@LDI-LR mass spectrometer (Waters). The instrument was operated in positive reflector mode. Acquisition mass range was $800-4000 \mathrm{Da}$. The instrument was calibrated on 8-10 reference masses from a tryptic digest of alcohol dehydrogenase. In addition, a near point lockmass correction for each sample spot was performed using adrenocorticotropic hormone fragment 18-39 $(\mathrm{MH}+2465.199)$ to achieve maximum mass accuracy. Typically 100 shots were combined and background subtracted. A peptide mass list was generated for the subsequent database search [16, 18]. Routinely, identifications were performed using matched spots from the purified adipocytes. Next, spots that turned out to be expressed significantly different between groups were excised from every individual gel and the identity of these spots was confirmed by MALDI-TOF MS or LCMSMS analysis.

\subsection{Database search}

The peptide mass list was searched with ProteinLynx Global Server v2.0.5 (Waters) or MASCOT search engine (http:// www.matrixscience.com) against the Swiss-Prot database (http://expasy.ch/sprot) for protein identification. One misscleavage was tolerated, carbamidomethylation was set as a fixed modification and oxidation of methionine as an optional modification. Taxonomy was set at Homo sapiens (human). The peptide mass tolerance was set to $100 \mathrm{ppm}$. No restrictions were made on the protein molecular weight and the $\mathrm{p} I$. A protein was regarded identified when it had a significant ProteinLynx or MASCOT probability score $(p<0.05)$ [18].

\subsection{Data processing}

Differentially expressed proteins were analyzed using GenMAPP gene map annotator and pathway profiling software (version 2.0) (http://www.genmapp.org) [19, 20] in order to find relevant biological pathways. Genedatabase Hs-Std 200507 was used together with contributed local mapps from 20050630 with beta version of the fat metabolism mapps created for the European Network of Excellence for Nutrigenomics NuGO (http://www.nugo.org) created at BiGCaT bioinformatics. From the 20051123 release onwards those mapps are part of the regular contributed mapps. For this purpose, proteins were identified with their Swiss-Prot primary identifier and categorized in a single column using positive numerical identifier for the experimental condition. The dataset and criterion file were evaluated using Mappfinder [20] that is built in the GenMAPP v2.0 software with both mapps derived from Gene Ontology (http://www.geneontology.org) and mapps specifically built for GenMAPP (socalled local mapps). The Mappfinder criterion was set to match all positive values (and thus all proteins present for any experimental condition). From the ranked list of mapps (based on z-scores) all mapps showing three or more changed proteins were considered relevant.

\subsection{Statistical analysis and calculations}

Data are expressed as mean \pm SEM.

Energy expenditure was calculated according to the equation of Weir [21] and fat oxidation was calculated according to the equations of Frayn [22]. In these calculations nitrogen excretion was assumed to be similar to daily nitrogen intake. The HOMA-index for insulin resistance $\left(\mathrm{HOMA}_{\mathrm{IR}}\right)$ was calculated from fasting glucose and insulin according to the equation of Matthews et al. [23]. For comparing postprandial responses the area under the curve was calculated according to the trapezium rule.

Statistical analysis was performed with SPSS 11.1 for Macintosh. Independent samples student's $t$-test (two-sided) was used to compare subject characteristics between HFO and LFO groups. Univariate ANOVA was done for correcting resting energy expenditure for fat free mass (FFM) with resting energy expenditure as dependent variable, group as fixed factor and FFM as covariate. Corrected resting energy expenditures between HFO and LFO groups were compared.

Differences in protein expression between HFO and LFO were tested by means of one-way ANOVA. At a $p$-level of 0.05 or smaller results were considered significantly different.

\section{Results}

\subsection{Constituting groups of high and low fat-oxidizing subjects}

Fasting respiratory quotient (RQ) and fasting fat oxidation values differed significantly $(p<0.02)$ between LFO and HFO groups. In Table 1 subject characteristics are depicted. No significant differences between high and low fat-oxidizing subjects were present for age, body weight, BMI, FFM, waist circumference, HOMA-index and fasting free fatty acid (FFA) concentrations. Subjects in the LFO group tended to be less heavy and to have lower mean waist circumference, mean basal FFA concentrations and both mean resting and postprandial energy expenditure but these tendencies did not reach significance. Frozen subcutaneous fat biopsies from these subjects were used to isolate protein, which was subsequently analyzed by 2-DE. In this way, a proteome pattern of approximately 1200 spots could be visualized. However, spot pattern comparison and identification of proteins learned that the protein samples contained a considerable amount of blood plasma proteins like hemoglobin and IgGs (Fig. 1A). Although not completely unexpected, their presence hampered the detection and quantitative comparison of adipocyte-specific proteins.

\subsection{The proteome of primary human adipocytes and of blood cells}

Using biopsy material it is fairly impossible to avoid mixed tissue-samples and contamination with blood. However, we 
Table 1. Subject characteristics

\begin{tabular}{|c|c|c|c|}
\hline & Low fat-oxidizers & High fat-oxidizers & $p$-value \\
\hline $\mathrm{N}(\mathrm{M} / \mathrm{FM})$ & $6(1 / 5)$ & $6(1 / 5)$ & \\
\hline Age (years) & $43.8 \pm 1.5$ & $37.8 \pm 3.9$ & 0.20 \\
\hline Weight (kg) & $87.0 \pm 5.1$ & $101.6 \pm 6.3$ & 0.10 \\
\hline BMI $\left(\mathrm{kg} / \mathrm{m}^{2}\right)$ & $33.2 \pm 2.1$ & $36.8 \pm 1.8$ & 0.22 \\
\hline $\mathrm{FFM}(\mathrm{kg})$ & $53.6 \pm 3.8$ & $58.1 \pm 4.9$ & 0.49 \\
\hline Waist $(\mathrm{cm})$ & $101.1 \pm 4.0$ & $113.4 \pm 4.1$ & 0.06 \\
\hline $\mathrm{HOMA}_{\mathrm{IR}}$ & $3.6 \pm 1.3$ & $3.6 \pm 1.0$ & 0.99 \\
\hline $\mathrm{REE}(\mathrm{KJ} / \mathrm{min})$ & $4.5 \pm 0.2$ & $5.5 \pm 0.5$ & 0.09 \\
\hline Adjusted REE $(\mathrm{KJ} / \mathrm{min})^{\mathrm{a})}$ & $4.7 \pm 0.2$ & $5.4 \pm 0.2$ & 0.05 \\
\hline Basal FFA concentration ( $\mu \mathrm{mol} / \mathrm{l})$ & $457.2 \pm 67.2$ & $672.9 \pm 91.7$ & 0.09 \\
\hline Fasting fat oxidation $(\mathrm{g} / \mathrm{min})$ & $0.037 \pm 0.005$ & $0.075 \pm 0.008$ & 0.01 \\
\hline Fasting fat oxidation as EN\% & $35.9 \pm 4.5$ & $55.8 \pm 3.0$ & 0.01 \\
\hline Fasting $\mathrm{RQ}$ & $0.85 \pm 0.02$ & $0.80 \pm 0.01$ & 0.01 \\
\hline Postprandial EE (AUC/min, KJ) & $4.9 \pm 0.2$ & $5.7 \pm 0.4$ & 0.08 \\
\hline Adjusted postprandial EE (AUC/min, KJ) & $5.6 \pm 0.18$ & $5.0 \pm 0.18$ & 0.05 \\
\hline Postprandial fat oxidation (AUC/min, g) & $0.050 \pm 0.006$ & $0.086 \pm 0.005$ & 0.01 \\
\hline Postprandial fat oxidation as $\%$ of EE & $40.9 \pm 3.4$ & $60.9 \pm 2.4$ & 0.01 \\
\hline Postprandial RQ (AUC/min) & $0.84 \pm 0.01$ & $0.78 \pm 0.01$ & 0.01 \\
\hline
\end{tabular}

$A U C$, area under the curve; $E E$, energy expenditure; REE, resting energy expenditure a) Energy expenditure corrected for FFM

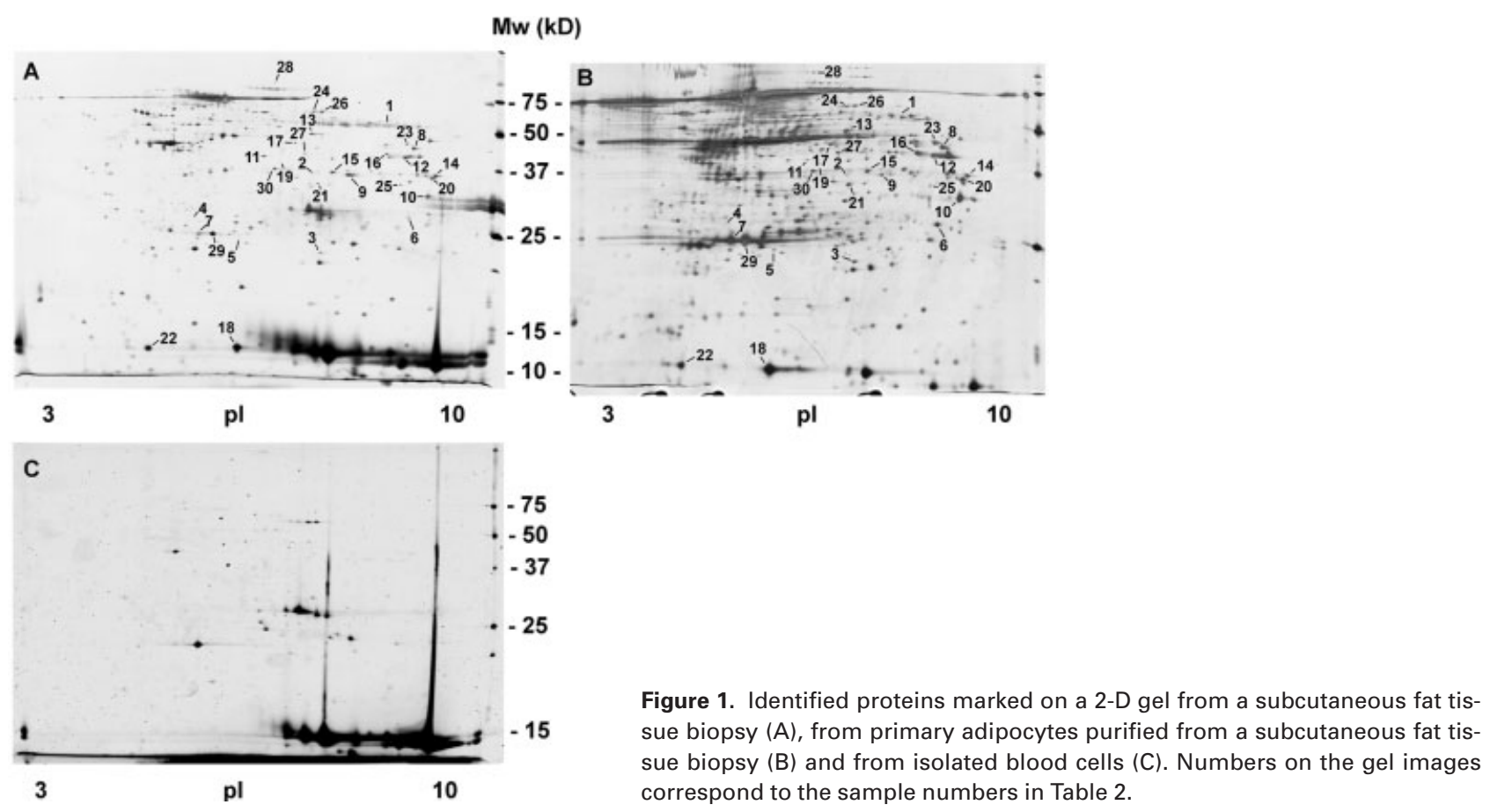

were exclusively interested in the differences of adipocytespecific proteins. We therefore decided to follow a novel strategy by constructing a human adipocyte-specific as well as a blood cell specific proteome map and use those for analysis of the biopsies (Fig. 1). For this purpose, primary adipocytes were purified from a subcutaneous fat tissue biopsy, from a healthy, lean, middle-aged female subject as described in Section 2. In addition, a human blood cell proteome was used to exclude most abundant proteins from leukocytes and erythrocytes. A proteome map consisting of 72 adipocyte-specific spots could be generated in this way. From those spots, 30 were identified by MS and correspond 
to 26 different proteins (Fig. 1A, Table 2). Most of them can be functionally classified as involved in the cellular and mitochondrial metabolism of glucose, fatty acids, amino acids and ketone bodies, in the respiratory chain and in the regulation of ROS.

\subsection{Differential adipocyte-specific proteins}

Biopsy proteome patterns of LFO and HFO groups were reexamined while focusing on the adipocyte-specific spots. This was achieved by matching the 72-spot adipocyte map with the individual biopsy proteome pattern. Only the spots that differed less than 1.2 times between high and low fat- oxidizing subjects (28 spots) were used for normalization. Afterwards, differentially expressed proteins were searched for. This resulted in the detection of 44 adipocyte-specific spots with a difference of more than 1.2 times between the high and low fat-oxidizing subject groups as measured by PD Quest analysis. Of those 44 spots, 15 were identified corresponding to 14 different proteins. Both LFO and HFO groups consisted of five females and one male. Removal of the male data did not notably influence the categorization of the proteins. In Table 2 all 30 identified spots are ranked in three categories according to magnitude of difference in expression. When the data were evaluated with the Mappfinder statistical analysis tool that is part of GenMAPP [24],

Table 2. Protein identification of adipocyte specific spots and expression difference between low or high fat oxidation

\begin{tabular}{|c|c|c|c|c|c|c|c|}
\hline Difference & Sample & $\begin{array}{l}\text { Accession } \\
\text { number }\end{array}$ & Protein description & $\begin{array}{l}\text { Expression } \\
\text { LFO/HFO }\end{array}$ & $\begin{array}{l}\text { MASCOT } \\
\text { score }\end{array}$ & $\begin{array}{l}\text { Sequence } \\
\text { coverage } \\
(\%)\end{array}$ & $\begin{array}{l}\text { Matched } \\
\text { peptides }\end{array}$ \\
\hline \multirow[t]{8}{*}{$\geq 1.5$} & 1 & Q02252 & $\begin{array}{l}\text { Methylmalonate-semialdehyde } \\
\text { dehydrogenase }\end{array}$ & $2.41^{\mathrm{a})}$ & 100 & 20 & 8 \\
\hline & 2 & P07355 & Annexin A2 & 2.28 & 71 & 20 & 6 \\
\hline & 3 & P04179 & Superoxide dismutase [Mn], Mt & $1.90^{\mathrm{a})}$ & 71 & 20 & 4 \\
\hline & 4 & P35232 & Prohibitin & $1.83^{\mathrm{a})}$ & 76 & 21 & 5 \\
\hline & 5 & P30048 & $\begin{array}{l}\text { Thioredoxin-dependent peroxide } \\
\text { reductase, Mt }\end{array}$ & 1.72 & 71 & 25 & 6 \\
\hline & 6 & P38117 & Electron transfer flavoprotein beta-subunit & 1.56 & 70 & 22 & 6 \\
\hline & 7 & O14975 & Very-long-chain acyl-CoA synthetase, partial & 1.51 & 55 & 8 & 5 \\
\hline & 8 & P00558 & Phosphoglycerate kinase 1 & -1.62 & 67 & 16 & 4 \\
\hline \multirow[t]{7}{*}{$\geq 1.2-<1.5$} & 9 & P07355 & Annexin A2 & $1.48^{\mathrm{a})}$ & 113 & 27 & 8 \\
\hline & 10 & Q16836 & $\begin{array}{l}\text { Short chain 3-hydroxyacyl-CoA } \\
\text { dehydrogenase, Mt }\end{array}$ & 1.26 & 76 & 16 & 6 \\
\hline & 11 & P16219 & $\begin{array}{l}\text { Acyl-CoA dehydrogenase, short-chain } \\
\text { specific, Mt }\end{array}$ & 1.21 & 67 & 17 & 6 \\
\hline & 12 & P04075 & Fructose-bisphosphate aldolase A & $-1.42^{\mathrm{a})}$ & 75 & 14 & 5 \\
\hline & 13 & P06733 & Alpha enolase & -1.32 & 89 & 27 & 9 \\
\hline & 14 & P04406 & $\begin{array}{l}\text { Glyceraldehyde-3-phosphate } \\
\text { dehydrogenase, liver }\end{array}$ & -1.31 & 54 & 18 & 4 \\
\hline & 15 & P52895 & Aldo-keto reductase family 1 member C2 & -1.22 & 90 & 15 & 5 \\
\hline \multirow[t]{15}{*}{$<1.2$} & 16 & P24752 & Acetyl-CoA acetyltransferase, Mt & 1.19 & 55 & 14 & 4 \\
\hline & 17 & 075874 & Isocitrate dehydrogenase [NADP], Cyt & 1.18 & 74 & 19 & 8 \\
\hline & 18 & P15090 & FABP & 1.18 & 107 & 59 & 7 \\
\hline & 19 & P14550 & Alcohol dehydrogenase [NADP+] & 1.16 & 69 & 18 & 5 \\
\hline & 20 & P40926 & Malate dehydrogenase, Mt & 1.13 & 88 & 28 & 7 \\
\hline & 21 & Q99685 & Monoglyceride lipase & 1.06 & 91 & 26 & 7 \\
\hline & 22 & P09382 & Galectin-1 & 1.04 & 73 & 41 & 5 \\
\hline & 23 & P42765 & AcetylCoA acyltransferase, Mt & 1.03 & 110 & 18 & 8 \\
\hline & 24 & P04040 & Catalase & 1.01 & 110 & 26 & 10 \\
\hline & 25 & P07355 & Annexin A2, N-term & 1.01 & 96 & 24 & 8 \\
\hline & 26 & P04040 & Catalase & -1.19 & 113 & 24 & 9 \\
\hline & 27 & P09972 & Fructose-bisphosphate aldolase C & -1.18 & 62 & 27 & 6 \\
\hline & 28 & P21399 & Iron-responsive element binding protein 1 & -1.10 & 122 & 19 & 13 \\
\hline & 29 & 014975 & Very-long-chain acyl-CoA synthetase, partial & -1.05 & 77 & 7 & 6 \\
\hline & 30 & P04083 & Annexin A1 & -1.03 & 94 & 28 & 8 \\
\hline
\end{tabular}

Cyt: cytoplasmic, Mt: mitochondrial

a) $p<0.05$ 
the glycolysis/gluconeogenesis pathway (see Fig. 2) came out with the highest score. Of the 14 differential proteins five fall into this pathway (fructose-bisphosphate aldolase A, phosphoglycerate kinase, fructose-bisphosphate aldolase C, alpha enolase, glyceraldehyde-3-phosphate dehydrogenase) and except for fructose-biphosphate aldolase $\mathrm{C}$ all are 1.3-1.8 times lower expressed in low fat-oxidizing persons.

\section{Discussion}

In this study we searched for proteomics differences in AT of obese subjects with a relatively low or a relatively high fatoxidation both during fasting conditions and after a high fat load. Groups were matched for body weight, age and FFM and there were no significant differences in $\mathrm{HOMA}_{\mathrm{IR}}$, waist circumference, fasting FFA concentrations and resting and postprandial energy expenditure. Since fat biopsies could not be taken from all subjects and because availability of a fat tissue biopsy specimen was a requirement for the present study, perfect matching was not possible. In the proteome analysis we focused on spots that were also detectable in purified human adipocytes but not in blood cells. It should be noted that the same spots in the biopsy proteome pattern could still be partly derived from other cell types. Nevertheless, as such they are an integral part of the AT proteome.

Proteome comparison of AT shows a higher concentration of mitochondrial proteins involved in the removal of ROS in the LFO group (Table 2). Superoxide dismutase catalyzes the conversion of the $\mathrm{O}_{2}$ ' superoxide anion into hydrogen peroxide, which in turn can be reduced to water by peroxidase and catalase [25]. Thioredoxin-dependent peroxide reductase, also known as mitochondrial peroxiredoxin 3 , is a member of a family of proteins that protect radical-sensitive enzymes from oxidative damage. It has been shown that obesity and type 2 diabetes mellitus are associated with an impaired functional capacity of skeletal muscle mitochondria which was found to correlate with the degree of insulin resistance [26, 27]. Recently, Choo et al. (2006) showed that adipocytes in diabetic mice also exhibit mitochondrial dysfunction [28]. Moreover, in mitochondria isolated from bovine heart tissue Cocco et al. [29] showed that mitochondrial ROS production is a consequence of selective inhibition of respiratory chain complex I and III by mainly long-chain unsaturated fatty acids. The inhibition of respiratory chain activity by FFA appears to precede ROS production [29]. Altogether, this suggests a somewhat impaired mitochondrial function in LFO vs HFO adipocytes with a higher ROS level.

As indicated above, mitochondria in AT of LFO subjects may be less efficient in ATP production. In this respect, the up-regulation of electron transfer flavoprotein beta-subunit in adipocytes of LFO compared to HFO can be regarded as part of a compensatory process. Electron transfer flavoprotein is an electron acceptor for the acyl-CoA dehydrogenases involved in fatty acid oxidation as well as for several dehydrogenases involved in amino acid metabolism [30].

Since the capacity to oxidize fat on whole body level is relatively low in LFO subjects, we expected an up-regulation of enzymes of the carbohydrate metabolism in various tissues. In contrast to our expectation, however, results from 2-DE show that, in AT, five enzymes of the glycolysis pathway were expressed in lower concentrations in LFO than in HFO. At the moment, these findings are difficult to explain. It might mean that fat oxidation is not altered in the AT of LFO subjects. Another explanation could be that both a lower fat and carbohydrate oxidation exist requiring other metabolic compensatory processes in AT.

The protein with the most different expression between both groups is methylmalonate-semialdehyde dehydrogenase (MMSDH, ALDH6A1) that has a 2.4 time higher expression level in LFO compared to HFO. MMSDH belongs to the aldehyde dehydrogenase family, a group of enzymes that catalyzes the oxidation of aliphatic and aromatic aldehydes [31]. Previous research in a preadipocyte cell line, 3T3L1 fibroblasts, revealed that MMSDH is an enzyme specific for the catabolism of the distal portion of valine. Its properties are unique among known aldehyde dehydrogenases because it is CoA-dependent and capable of conserving energy in the form of a CoA-ester [31, 32]. It catalyzes the irreversible conversion of methylmalonate-semialdehyde to propionyl$\mathrm{CoA}$ and $\mathrm{CO}_{2}$ (Fig. 3). As Fig. 3 shows, MMSDH is the only enzyme out of the five identified enzymes from the described pathway that was expressed differentially between the groups suggesting that, as in mouse 3T3-L1 cells, MMSDH is a rate limiting enzyme of this pathway in human adipocytes [32]. Although cell studies have shown that valine catabolism can provide carbon atoms for fatty acid synthesis [32], a slightly higher valine degradation in adipocytes of LFO subjects, as suggested by our results, may compensate for the lower glycolytic capacity and, possibly, a lower fat oxidation in AT. The low glycolytic capacity may lead to reduced amounts of pyruvate, which normally is converted to acetyl$\mathrm{CoA}$ and oxaloacetate for the TCA-cycle. By the higher concentration of prohibitin, which inhibits pyruvate carboxylase [33], the route to oxaloacetate is turned down in LFO subjects assuring the production of acetylCoA. The depletion of oxaloacetate can be compensated for by the conversion of valine to propionylCoA (Fig. 3), which in turn can be readily converted into succinylCoA. Interestingly, depletion of oxaloacetate may inhibit fatty acid oxidation [32, 33]. Unfortunately, at the moment antibodies against MMSDH for routine analysis of various tissues are not available.

Since low fat-oxidizers are less capable in using fatty acids as energy source as measured at whole body level [3], they have to derive energy from other sources like carbohydrates or proteins. Whether whole body protein oxidation was different between groups is not clear since this was not measured in the NUGENOB trial because under normal conditions protein oxidation is assumed to be similar to protein intake. Since differences in metabolic pathways in AT 


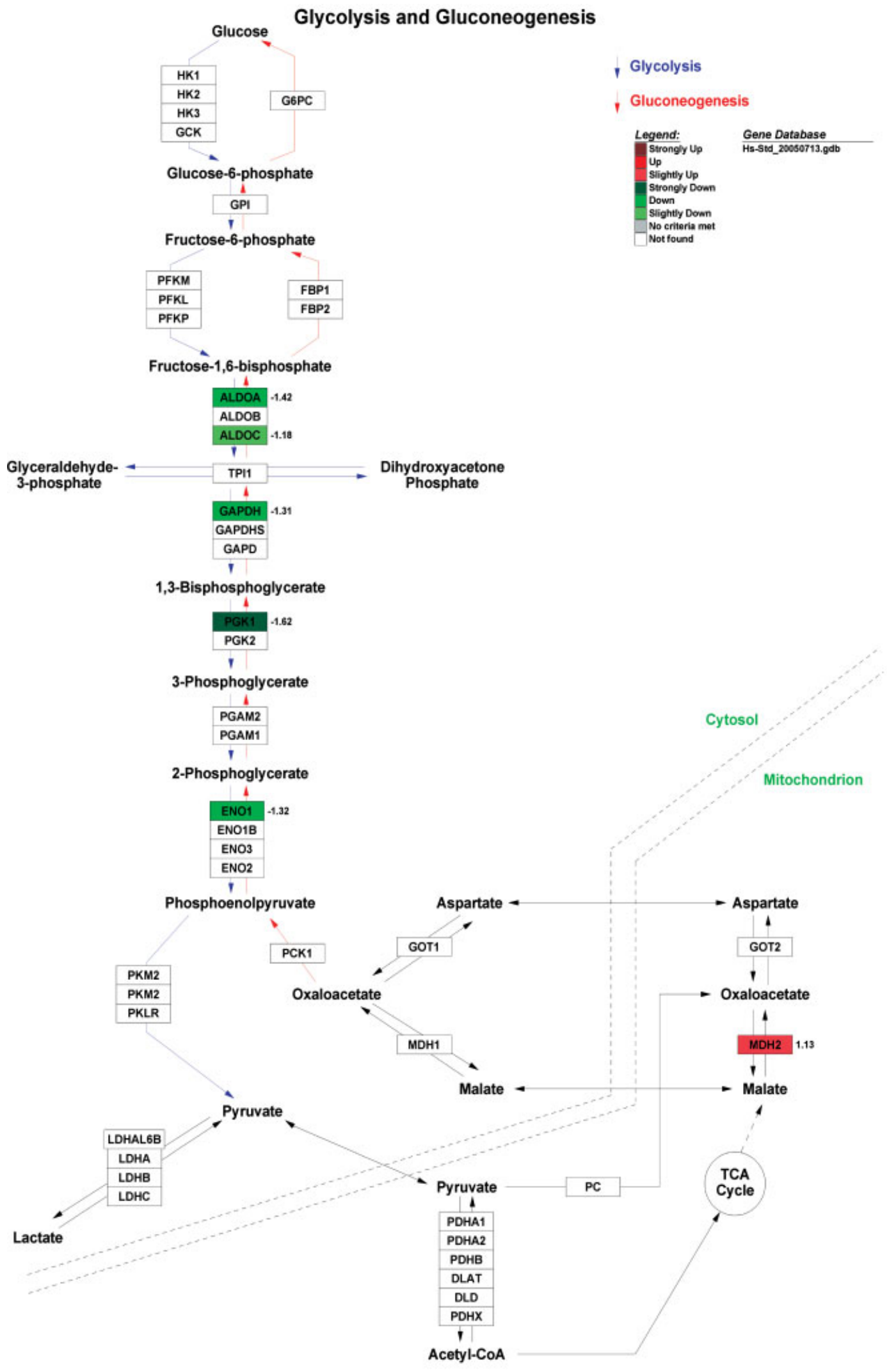

Figure 2. Glycolysis and gluconeogenesis pathway LFO vs HFO. 


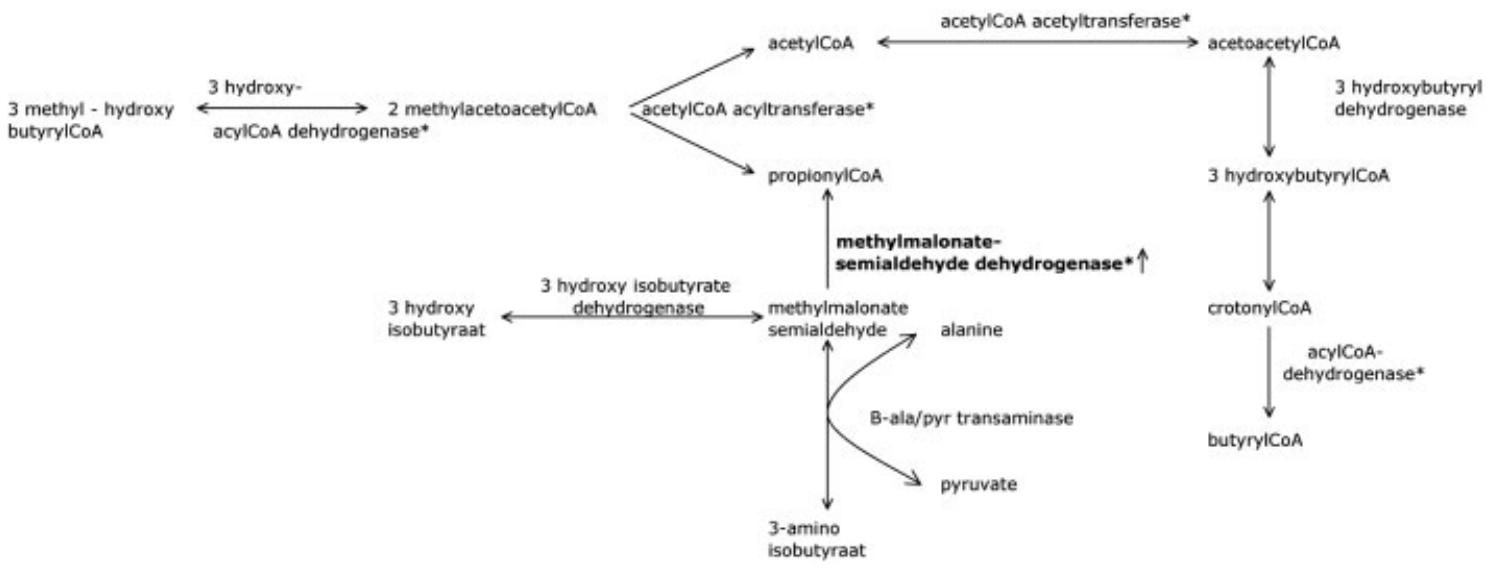

Figure 3. Pathway in which MMSDH is involved. *Indicates identified enzymes (see Table 2).

could have a genetic origin, the possibility exists that those differences are reflected on whole body level. Micro-array data have shown that the enzyme MMSDH is also expressed in human skeletal muscle suggesting that this may contribute to a higher $\mathrm{CO}_{2}$ production and a higher RQ in LFO subjects. To determine whether valine catabolism in LFO subjects is also increased in oxidizing tissues and to find out how this can affect substrate utilization at whole body level, further research is required. Eventually, such knowledge may help to prevent obesity by measures based on personalized proteomic parameters.

In conclusion, the present study shows that a low fat oxidative capacity is accompanied by ROS scavenger up-regulation in the mitochondria of AT. Moreover, our findings indicate that in AT glycolysis is less active, while protein oxidation, in particular valine catabolism at the level of the enzyme MMSDH, is higher in LFO compared to HFO subjects. These differences in the metabolic status of AT may explain some of the whole body metabolic differences related to oxidative capacity.

This study has received support from the NUGENOB (NUtrient-GENe interaction in human OBesity-implications for dietary guidelines) project supported by the European Commission (contract no. QLK1-CT-2000-00618).

\section{References}

[1] Ravussin, E., Bogardus, C., Energy balance and weight regulation: genetics versus environment. Br. J. Nutr..2000, 83, S17-S20.

[2] Weinsier, R. L., Hunter, G. R., Heini, A. F., Goran, M. I. et al., The etiology of obesity: Relative contribution of metabolic factors, diet, and physical activity. Am. J. Med. 1998, 105, 145-50.

[3] Giacco, R., Clemente, G., Busiello, L., Lasorella, G. et al., Insulin sensitivity is increased and fat oxidation after a high- fat meal is reduced in normal-weight healthy men with strong familial predisposition to overweight. Int. J. Obes. Relat. Metab. Disord. 2004, 28, 342-348.

[4] Thomas, C. D., Peters, J. C., Reed, G. W., Abumrad, N. N. et al., Nutrient balance and energy expenditure during ad libitum feeding of high-fat and high-carbohydrate diets in humans. Am. J. Clin. Nutr. 1992, 55, 934-942.

[5] Raben, A., Andersen, H. B., Christensen, N. J., Madsen, J. et al., Evidence for an abnormal postprandial response to a high-fat meal in women predisposed to obesity. Am. J. Physiol. 1994, 267, E549-559.

[6] Astrup, A., Buemann, B., Christensen, N. J., Toubro, S., Failure to increase lipid oxidation in response to increasing dietary fat content in formerly obese women. Am. J. Physiol. 1994, 266, E592-E599.

[7] Zurlo, F., Lillioja, S., Esposito-Del Puente, A., Nyomba, B. L. et al., Low ratio of fat to carbohydrate oxidation as predictor of weight gain: Study of 24-h RQ. Am. J. Physiol. 1990, 259, E650-E657.

[8] Flatt, J. P., Importance of nutrient balance in body weight regulation. Diabetes Metab. Rev. 1988, 4, 571-581.

[9] Petersen, M., Taylor, M. A., Saris, W. H., Verdich, C. et al., Randomized, multi-center trial of two hypo-energetic diets in obese subjects: high- versus low-fat content. Int. J. Obes. (Lond) 2005, 30, 552-560.

[10] Blaak, E., Hul, G., Verdich, C., Stich, V. et al., Fat oxidation before and after a high fat load in the obese insulin resistant state. J. Clin. Endocrinol. Metab. 2006, 91, 1462-1469.

[11] Rodbell, M., Metabolism of isolated fat cells. I. Effects of hormones on glucose metabolism and lipolysis. J. Biol. Chem. 1964, 239, 375-380.

[12] van der Kallen, C. J., Voors-Pette, C., Bouwman, F. G., Keizer, H. A. et al., Evidence of insulin resistant lipid metabolism in adipose tissue in familial combined hyperlipidemia, but not type 2 diabetes mellitus. Atherosclerosis 2002, 164, 337-346.

[13] Bradford, M. M., A rapid and sensitive method for the quantitation of microgram quantities of protein utilizing the principle of protein-dye binding. Anal. Biochem. 1976, 72, 248254.

[14] Rabilloud, T., Adessi, C., Giraudel, A., Lunardi, J., Improvement of the solubilization of proteins in two-dimensional 
electrophoresis with immobilized pH gradients. Electrophoresis 1997, 18, 307-316.

[15] Gorg, A., Obermaier, C., Boguth, G., Harder, A. et al., The current state of two-dimensional electrophoresis with immobilized pH gradients. Electrophoresis 2000, 21, 10371053.

[16] Bouwman, F., Renes, J., Mariman, E., A combination of protein profiling and isotopomer analysis using matrix-assisted laser desorption/ionization-time of flight mass spectrometry reveals an active metabolism of the extracellular matrix of 3T3-L1 adipocytes. Proteomics 2004, 4, 3855-3863.

[17] Shevchenko, A., Wilm, M., Vorm, O., Mann, M., Mass spectrometric sequencing of proteins silver-stained polyacrylamide gels. Anal. Chem. 1996. 68. 850-858.

[18] Bouwman, F., Suylen, D., Renes, J., Mariman, E., Evaluation and improving the success rate of protein identification by peptide mass fingerprinting using matrix-assisted laser desorption/ionization time-of-flight mass spectrometry. Rapid Commun. Mass Spectrom. 2005, 19, 2465-2468.

[19] Dahlquist, K. D., Salomonis, N., Vranizan, K., Lawlor, S. C. et al., GenMAPP, a new tool for viewing and analyzing microarray data on biological pathways. Nat. Genet. 2002, 31, 1920.

[20] Doniger, S. W., Salomonis, N., Dahlquist, K. D., Vranizan, K. et al., MAPPFinder: using Gene Ontology and GenMAPP to create a global gene-expression profile from microarray data. Genome Biol. 2003, 4, R7.

[21] Weir, J. B., New methods for calculating metabolic rate with special reference to protein metabolism. J. Physiol. 1949, 109, 1-9.

[22] Frayn, K. N., Calculation of substrate oxidation rates in vivo from gaseous exchange. J. Appl. Physiol. 1983, 55, 628-634.

[23] Matthews, D. R., Hosker, J. P., Rudenski, A. S., Naylor, B. A. et al., Homeostasis model assessment: insulin resistance and beta-cell function from fasting plasma glucose and insulin concentrations in man. Diabetologia 1985, 28, 412-419.

[24] Renes, J., Bouwman, F., Noben, J. P., Evelo, C. et al., Protein profiling of 3T3-L1 adipocyte differentiation and (tumor necrosis factor alpha-mediated) starvation. Cell. Mol. Life Sci. 2005, 62, 492-503.

[25] Stryer, L., Biochemistry, W. H. Freeman and Company, New York 1997.

[26] Kelley, D. E., He, J., Menshikova, E. V., Ritov, V. B., Dysfunction of mitochondria in human skeletal muscle in type 2 diabetes. Diabetes 2002, 51, 2944-2950.

[27] Petersen, K. F., Befroy, D., Dufour, S., Dziura, J. et al., Mitochondrial dysfunction in the elderly: Possible role in insulin resistance. Science 2003, 300, 1140-1142.

[28] Choo, H. J., Kim, J. H., Kwon, O. B., Lee, C. S. et al., Mitochondria are impaired in the adipocytes of type 2 diabetic mice. Diabetologia 2006, 49, 784-791.

[29] Cocco, T., Di Paola, M., Papa, S., Lorusso, M., Arachidonic acid interaction with the mitochondrial electron transport chain promotes reactive oxygen species generation. Free Radic. Biol. Med. 1999, 27, 51-59.

[30] Spaan, A. N., ljlst, L., van Roermund, C. W., Wijburg, F. A. et al., Identification of the human mitochondrial FAD transporter and its potential role in multiple acyl-CoA dehydrogenase deficiency. Mol. Genet. Metab. 2005, 86, 441-447.

[31] Kedishvili, N. Y., Popov, K. M., Rougraff, P. M., Zhao, Y. et al., CoA-dependent methylmalonate-semialdehyde dehydrogenase, a unique member of the aldehyde dehydrogenase superfamily. cDNA cloning, evolutionary relationships, and tissue distribution. J. Biol. Chem. 1992, 267, 19724-19729.

[32] Kedishvili, N. Y., Popov, K. M., Jaskiewicz, J. A., Harris, R. A., Coordinated expression of valine catabolic enzymes during adipogenesis: analysis of activity, mRNA, protein levels, and metabolic consequences. Arch. Biochem. Biophys. 1994, 315, 317-322.

[33] Vessal, M., Mishra, S., Moulik, S., Murphy, L. J., Prohibitin attenuates insulin-stimulated glucose and fatty acid oxidation in adipose tissue by inhibition of pyruvate carboxylase. FEBS J. 2006, 273, 568-576. 